\title{
A CONSTITUTiOnAl Future FOR Abortion Rights in CANADA
}

\author{
JOANNA N. ERDMAN*
}

\begin{abstract}
In 2015, Abortion Access Now PEI legally challenged the restrictive abortion policy of Prince Edward Island. This article studies their challenge as a unique case in the building of a constitutional future for abortion rights in Canada. The article tracks how AAN PEI drew on classic rule of law arguments of transparency, accountability, and constitutional justice to shape and claim abortion rights as democratic rights, an entitlement to fully and equally participate in and benefit from the health care system as a fundamental social institution of the state.
\end{abstract}

\section{TABLE OF CONTENTS}

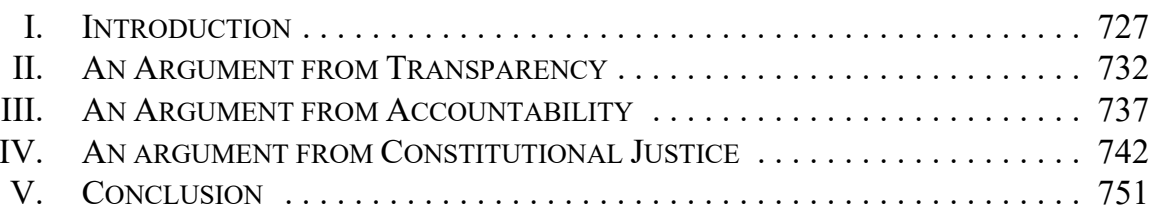

In public regulation of this sort there is no such thing as absolute and untrammeled "discretion", that is that action can be taken on any ground or for any reason that can be suggested to the mind of the administrator. ${ }^{1}$

\section{INTRODUCTION}

On 5 January 2016, Professor Colleen MacQuarrie waited for the elevator at the Prince Edward Island Government Administration Building. When the elevator arrived, she stepped in and stood beside provincial Premier Wade MacLauchlan. As they ascended, he asked, "You're coming up to see us this morning?" Indeed she was. ${ }^{2}$ MacQuarrie is a founding member of Abortion Action Now PEI (AAN PEI), an organization of veteran local abortion rights activists. On that day, she was delivering notice to the Prince Edward Island government of AAN PEI's intention to legally challenge the province's abortion policy. ${ }^{3}$

MacBain Chair in Health Law and Policy, Assistant Professor, Schulich School of Law, Dalhousie University. I am indebted to the legal research and writing of Nasha Nijhawan and Kelly McMillan, Nijhawan McMillan Barristers and Maureen Kirkpatrick, Women's Legal Education and Action Fund (LEAF). In full disclosure, I participated in advocacy meetings and served on a LEAF advisory committee in relation to this case.

Roncarelli $v$ Duplessis, [1959] SCR 121 at 140 [Roncarelli].

Personal communication from Colleen MacQuarrie, University of Prince Edward Island (5 January 2016) [on file with author]; Letter from Nasha Nijhawan, Nijhawan McMillan Barristers to Michele Dorsey, Deputy Attorney General re: Abortion Access Now PEI Inc. v. Government of PEI (5 January 2016) [on file with author] (notice of intended proceedings under section 10(2) of the Crown Proceedings Act, RSPEI 1988, c C-32).

3 Nijhawan McMillan Barristers in Halifax, Nova Scotia represented AAN PEI in their legal challenge, with the support of the Women's Legal Education and Action Fund, a national, equality rights organization: LEAF, Press Release, "LEAF Proudly Supports Abortion Access Now PEI's Legal Challenge to Prince Edward Island's Discriminatory Abortion Policy" (5 January 2016), online: $<$ www.leaf.ca/leaf-proudly-supports-abortion-access-now-peis-legal-challenge-to-prince-edwardislands-discriminatory-abortion-policy/> [LEAF, "Abortion Access Now"]. See also "P.E.I. Abortion Advocates to Sue for Access on Island," CBC News (5 January 2016), online: <www.cbc.ca/news/ canada/prince-edward-island/abortion-lawsuit-pei-1.3389889>; Teresa Wright, "Advocacy Group Suing 
In 1988, the Supreme Court of Canada struck down the country's criminal law on abortion. ${ }^{4}$ Immediately thereafter, Prince Edward Island passed a legislative resolution opposing the provision of abortion services on the Island. ${ }^{5}$ Since that time, through various regulatory actions, the government has endeavoured to keep its policy promise of an abortion-free island. When AAN PEI filed its notice of legal challenge, the government policy was to refer women to hospital-based services off-Island, and to provide limited public funding for these services. ${ }^{6}$ AAN PEI intended to challenge the policy and its enforcement as ultra vires of statutory authority and as unconstitutional ${ }^{7}$ in violation of the Canadian Charter of Rights and Freedoms. ${ }^{8}$

AAN PEI never had its day in court. On 31 March 2016, Premier MacLaughan announced that his government would revise its abortion policy, and shared plans to open a hospitalbased reproductive health clinic on the Island. ${ }^{9}$ The Premier acknowledged that the current policy was likely "contrary to equality rights guaranteed by the Canadian Charter of Rights and Freedoms as well as Charter guarantees of security of the person." ${ }^{10} \mathrm{He}$ concluded, "[T] he most responsible approach is to revise the policy... [We] recognize our obligation to provide timely and professional health care, without discrimination."11 As to why the government was now ready to abandon a policy it had defended resolutely for decades, the Premier replied only that "the character of all places changes and evolves.... It's one of those things that comes at its time."12 MacQuarrie listened to the announcement with tears in her eyes. She too thought of the character of this place: "I have listened to women's stories and

PEI Government Over Lack of Abortion Access," The Guardian (5 January 2016), online: $<$ www.theguardian.pe.ca/News/Local/2016-01-05/article-4393918/Advocacy-group-suing-P.E.Igovernment-over-lack-of-abortion-access/1>.

$4 \quad R$ v Morgentaler, [1988] 1 SCR 30 [Morgentaler].

"Resolution No 17," Journal of the Legislative Assembly of Prince Edward Island, 57th Parl, 3rd Sess, Daily Journal (22 February 1988, 29 March 1988, 7 April 1988) at 11, 90-91, 117-18, online: <www.peildo.ca/fedora/repository/leg:3295> ["Resolution 17"]. The resolution exempts abortion services necessary to save the life of the pregnant woman, which reflects a general classificatory scheme used in abortion regulation. Such services are often referred to as "termination of pregnancy," whereas the term "abortion" is often reserved for voluntary or elective terminations. In other words, the termination of pregnancy when necessary to save the life of the pregnant women is not considered to be an abortion in common or policy parlance.

6 The government funded abortion services provided at the Queen Elizabeth II Health Sciences Centre in Halifax, Nova Scotia, and as of 1 July 2015, the Moncton Hospital, in Moncton, New Brunswick. The province funded physician and hospital costs, but all incidental and travel expenses were generally paid out-of-pocket. Low-income patients were eligible for bus fare to and from the hospital: Health PEI, "Abortion Services," online: <www.healthpei.ca/abortionservices $>$. See also "Abortion Access Made Easier for P.E.I. Women," CBC News (2 June 2015), online: <www.cbc.ca/news/canada/prince-edwardisland/ abortion-access-made-easier-for-p-e-i-women-1.3096669>.

Abortion Access Now PEI Inc $v$ The Government of Prince Edward Island, online: <www.leaf.ca/wpcontent/uploads/2016/01/AAN-PEI-050116-Draft-Notice-of-Application.pdf $>$ (Draft Application) [AAN PEI (Draft Notice of Application)].

$8 \quad$ Canadian Charter of Rights and Freedoms, Part I of the Constitution Act, 1982, being Schedule B to the Canada Act 1982 (UK), 1982, c 11 [Charter].

9 Sean Fine, "PEI Drops Opposition to Abortion, Plans to Provide Access by Year's End," The Globe and Mail (31 March 2016), online: <www.theglobeandmail.com/news/national/pei-to-allow-abortions/ article29474278/>; Sara Fraser \& Jesara Sinclair, “Abortion Services Coming to P.E.I., Province Announces," CBC News (31 March 2016), online: <www.cbc.ca/news/canada/prince-edward-island/peiabortion-reproductive-rights-1.3514334>; Graham Slaughter, "P.E.I. to Establish Abortion Clinic on the Island," CTV News (31 March 2016), online: <www.ctvnews.ca/health/p-e-i-to-establish-abortion-clinicon-the-island-1.2840104>.

10 The Canadian Press, "P.E.I. to Provide Access to Abortions by End of 2016" (31 March 2016), online: $<$ https://www.thestar.com/news/canada/2016/03/31/pei-agrees-to-provide-abortions-by-end-of2016.html>.

11 Anna Mehler Paperny, "Facing Lawsuit, PEI will Start Offering Abortions” Global News (1 April 2016), online: <globalnews.ca/news/2610660/facing-lawsuit-pei-will-start-offering-abortions/>.

Fine, supra note 9. 
I heard how horrible the situation had been.... [T] he punishing regime ... the women had gone through."13

The Prince Edward Island government reformed its abortion policy with no judicial review. No case was won nor litigated. There was no judgment - no Supreme Court pronouncement. AAN PEI's challenge is nonetheless an important constitutional case for abortion law in Canada, albeit one outside the paradigms of formal lawmaking or adjudication, an often neglected form of constitutional change. ${ }^{14}$ In this case, a group of mobilized citizens persuaded the government to adopt a new understanding of constitutional abortion rights, and so conferred upon it the authority to enforce these rights in new ways.

Abortion rights in Canada are most commonly understood by reference to Justice Wilson's opinion in Morgentaler. ${ }^{15}$ In Morgentaler, a majority of the Supreme Court struck down the criminal abortion law because it violated the right to security of person, narrowly defined as a right to access health care in a safe and timely manner. Justice Wilson, however, would have decided the case under the right to liberty, and it is her opinion that has proved most influential, being widely endorsed and often taken to represent the Morgentaler ruling as a whole. ${ }^{16}$ A criminal law on abortion, she wrote, takes from a woman a fundamental personal decision of an intimate and private nature, depriving a woman of her right to develop her potential to the full, to plan her own life and to make her own choices. ${ }^{17}$ Justice Wilson's reasoning is classically liberal, conceiving of women's reproductive freedom as the pursuit of self-interest unencumbered by the state. The right to liberty, she wrote, erects "around each individual, metaphorically speaking, an invisible fence over which the state will not be allowed to trespass." ${ }^{18}$ In this liberal articulation, abortion rights radically separate individual and community, citizen and state. Freedom is identified with free enterprise rather than state intervention, with the private rather than public sphere.

In Prince Edward Island, however, women's reproductive freedom was threatened not by state interference, but rather by state indifference. The injustice of the abortion policy was that it left many women alone, requiring them to seek and access services without state resources or support. Sheila Shaver credits this indifference to the contradiction of liberal abortion rights, which legitimate the withdrawal of the state and the privatization of abortion care. ${ }^{19}$ State indifference in Prince Edward Island was exemplified in the government seeing little need to offer reason or justification for its policy, suggesting rather that whether and how they delivered services was within their absolute and unfettered discretion. Women were to accept the terms of the policy without recourse or remedy, there being no constitutional

Teresa Wright, “Change in P.E.I.'s Abortion Policy Long Time Coming,” The Guardian (1 April 2016), $<$ www.theguardian.pe.ca/News/Local/2016-04-01/article-4483618/Change-in-P.E.I.s-abortion-policylong-time-coming/1>.

14 See Reva Seigel, "Constitutional Culture, Social Movement Conflict and Constitutional Change: The Case of the de De Facto ERA" (2006) 94:5 Cal L Rev 1323 at 1324-25, 1328-29 (discussion of popular constitutionalism)

Morgentaler, supra note 4 at 161-72.

See Chris Kaposy \& Jocelyn Downie, "Judicial Reasoning about Pregnancy and Choice" (2008) 16:1 Health LJ 281 at 290.

Morgentaler, supra note 4 at 163-72.

Ibid at 164 .

Sheila Shaver, "Body Rights, Social Rights and the Liberal Welfare State" (1994) 13:39 Critical Social Policy 66 at 69-70. 
right to abortion or any other health care service. ${ }^{20}$ When publicly challenged on the policy, the government responded simply that "there is no desire to broaden the current abortion services," ${ }^{21}$ rather "we believe the status quo is working." 22 Belief and desire were substituted for evidence and reason.

While not disclaiming the liberal tradition, in their public statements, the popular press, and in their formal application, AAN PEI cast constitutional abortion rights in a new way. They claimed abortion rights against state indifference, not interference, drawing on a republican tradition of liberty, which promises that legal subjects will not be abandoned to arbitrary power, that is, power exercised in ways indifferent to the purposes that justify its use and to the interests of those subject to it. ${ }^{23}$ This ideal of liberty assumes not a separation of women from the state, but a belief in the worth of and respect for women as participants in and beneficiaries of public power. Abortion rights in this tradition seek not to sever women from public life but to mediate the relationship between women and the state, and to thereby shape the use of its power for women's security, equality, and freedom in the public interest. AAN PEI thus argued that the abortion policy was constitutionally unjust not only because of its impact on women's individual rights to liberty, security, and equality under the Charter, but more fundamentally, because of its democratic effects on the full and equal status of Island women as citizens, entitled to benefit from the institutions of the state, among them, the public health care system. When the Premier credited policy reform to a change in the character of the place, perhaps he intended reference to a change of democratic culture, where government would no longer subject Island women to a punishing regime but would rather honour its obligation to care for and about them.

AAN PEI was not the first to articulate a democratic alternative for constitutional abortion rights in Canada. Shortly after Morgentaler was handed down, Hester Lessard imagined a possible future for abortion rights focused on the political efficacy of their holders to build social institutions that speak to a community's needs and values, including those related to sexuality and reproduction. ${ }^{24}$ Understanding abortion rights as a claim for inclusion and participation, she wrote, "entails a different view of the state, one in which state power is the mediator and facilitator of rights rather than antithetical to freedom... [T] he language of

For a rich discussion on the question of positive government obligations in the health care context, see Colleen M Flood \& YY Brandon Chen, Charter Rights \& Health Care Funding: A Typology of Canadian Health Rights Litigation" (2010) 19:3 Annals Health L 479; Matthew Rottier Voell, "PHS Community Services Society v Canada (Attorney General): Positive Health Rights, Health Care Policy, and Section 7 of the Charter" (2012) 31 Windsor Rev Legal Soc Issues 41; Mel Cousins, "Health Care and Human Rights After Auton and Chaoulli" (2009) 54:4 McGill LJ 717; Martha Jackman, "Charter Review as a Health Care Accountability Mechanism in Canada" (2010) 18 Health LJ 1. 21 "No Need for Local Abortion Services, Says Province," CBC News (26 May 2014), online: <www. 1.2654757> [CBC News, "No Need for Local Abortion Services"].

22 Ibid. See also Kevin Bissett, "Debate Over Access to Abortion in Prince Edward Island Intensifies," The Globe and Mail (27 May 2014), online: <www.theglobeandmail.com/news/national/debate-over-accessto-abortion-in-prince-edward-island-intensifies/article18877480/>.

23 For a discussion of the republic tradition of liberty, see David Dyzenhaus, "Rand's Legal Republicanism" (2010) 55:3 McGill LJ 491 at 500, 508-10.

24 Hester Lessard, "Relationship, Particularity, and Change: Reflections on $R v$ Morgentaler and Feminist Approaches to Liberty" (1991) 36:2 McGill LJ 263. Lessard notes that Justice Wilson acknowledged this point to some extent in her Morgentaler, supra note 4, judgment when she described women's selfdetermination as a struggle for inclusion in society, rather than exclusion from the state: "The decision is one that will have profound psychological, economic and social consequences for the pregnant woman.... It is a decision that deeply reflects the way the woman thinks about herself and her relationship to others and to society at large" (ibid at 171). 
rights becomes the language of democratic interrelationships rather than the language of separation and boundaries." ${ }^{25}$ Lessard's theory recognized the link between the deprivation of women's reproductive liberty, security, and equality and disempowerment within political and public life, thus configuring abortion rights as a renewed source of democratic power.

The challenge and reform of Prince Edward Island's abortion policy is a unique case study in the building of a constitutional future for abortion rights in Canada. Scholars have written of alternative visions for reproductive justice, but the activists of AAN PEI gave legal form to this future. ${ }^{26}$ The purpose of this article is to study and learn from their legal arguments: the way in which they shaped and claimed abortion rights as democratic rights, an entitlement to participate in and to benefit from the exercise of public power, and to thereby build a just and inclusive health care system. While of particular significance for the future of reproductive justice, a democratic role for constitutional rights speaks generally to a future for health law and policy in Canada. Alana Klein, for example, has written powerfully of a new emphasis on human rights in health as a guarantee of citizen enfranchisement, a means not only to protect citizens' interests from a repressive state, but also to ensure that they are accounted for in the design and administration of health systems. ${ }^{27}$

The article tracks AAN PEI's legal arguments along three principles of the rule of law: transparency, accountability, and constitutional justice. With no claim to explicit awareness or intention, AAN PEI drew on classic rule of law ideas in their challenge reflecting the fact that constitutionalism and the rule of law lie at the centre of the Canadian system of democratic government, with arbitrariness in the exercise of public power central to both. ${ }^{28}$ In its largest sense, the rule of law captures something of the normative relationship between citizen and state, more particularly, a constraint on the state's exercise of public power against its citizens deriving from fundamental norms of the constitutional order. ${ }^{29}$ In challenging the arbitrariness of the abortion policy, AAN PEI drew on this constitutional morality to mediate the relationship between women and the state, and to thereby build a legal foundation for women's full and equal citizenship within the state. ${ }^{30}$

Part II of this article focuses on the principle of transparency and the argument that the government's refusal to make clear its abortion policy profoundly undermined any

25 Lessard, ibid at 306

26 Lessard, ibid. In the Canadian context, see also Rachael Johnstone, "The Politics of Abortion in New Brunswick" (2014) 36:2 Atlantis 73; Sarah Marie Weibe \& Erin Marie Konsmo, "Indigenous Body as Contaminated Site? Examining Struggles for Reproductive Justice in Aamjiwnaang" in Stephanie Paterson, Francesca Scala \& Marlene K Sokolon, Fertile Ground: Exploring Reproduction in Canada (Montreal: McGill-Queen's University Press, 2014) 325 at 331-38; Stephanie Paterson, Francesca Scala \& Marlene K Sokolon, "Conclusion" in Paterson, Scala \& Sokolon (ibid) 359 at 363.

27 Alana Klein, "So Long as You Have Your Health: Health Care Distribution in Canada" (2012) 30:2 Windsor YB Access Just 247 at 264.

28 Reference re Secession of Quebec, [1998] 2 SCR 217 at paras 70-78 [Secession Reference]. For a discussion of the conceptual relationship between arbitrariness and the rule of law, see also Mary Liston, "Witnessing Arbitrariness: Roncarelli v. Duplessis Fifty Years On" (2010) 55:3 McGill LJ 689 [Liston, "Witnessing Arbitrariness"].

$29 \quad$ See David Dyzenhaus, "The Deep Structure of Roncarelli v. Duplessis" (2004) 53 UNBLJ 111 at 124-28 (discussing Roncarelli, supra note 1).

Matthew Lewans explains how the concept of citizenship in the rule of law embeds significant normative content, including democratic rights to participate in and to be treated with consideration and respect in the exercise of political power, as well as, to enjoy equally in the immunities and privileges of the state: Matthew Lewans, "Roncarelli's Green Card: The Role of Citizenship in Randian Constitutionalism" (2010) 55:3 McGill LJ 537. 
democratic character or defence of the state policy. In the very exposure of the provincial abortion policy, AAN PEI thus claimed access to information as a constituent element of abortion rights in a democratic tradition. Part III focuses on the principle of accountability and the argument that the abortion policy was without legal authority, being inconsistent with the values and the purpose of the statutory power under which it was enacted, the Health Services Act. ${ }^{31}$ In this respect, abortion rights are claimed not against state intervention, but for state protection through the democratic promise of legislation. Part IV focuses on the principle of constitutional justice and the argument that the abortion policy ran afoul of substantive values inherent in the constitutional order, beyond the realm of ordinary law. To run this argument, AAN PEI drew on two national sources of law, the Canada Health Act ${ }^{32}$ and the Charter. ${ }^{33}$ By collecting and organizing these arguments within a single rule of law genre, this article further seeks to contribute to Canadian theorizing on the rule of law in popular constitutionalism, that is, citizen resistance against arbitrary public power independent of judicial review. ${ }^{34}$

\section{An ARgument From TransparenCy}

The arbitrariness of the Prince Edward Island abortion policy began with the fact that no singular, written policy ever existed — at least none publicly available in Cabinet documents, Royal Gazette proclamations, or political party minutes ${ }^{35}$ Freedom of information requests yielded no such policy document from either the Department of Health and Wellness or Health PEI. ${ }^{36}$ Rather the question of who or what was responsible for the unavailability of local services was a constant contention in Prince Edward Island abortion debates. In 2011, Dr. Richard Wedge, then Executive Director of Medical Affairs at Health PEI, asserted that there was no regulatory barrier to abortion services on the Island: "If a physician applied for privileges to do abortions on P.E.I., and they had the skills, the training necessary to do it, then they could get privileges for that on P.E.I." ${ }^{37}$ There were no local services, he claimed, because no doctor had ever applied. The government, in other words, denied any hand in a failing free market for local abortion care. What services were available, with what public resources or support, was also unclear. In 2011, the Prince Edward Island Medical Society requested the government clarify its policy on abortion, and only later that year did Health PEI post basic information on its website about the availability of public funding for out-ofprovince abortion services. ${ }^{38}$

RSPEI 1988, c H-1.6.

RSC 1985, c C-6.

Supra note 8.

See Evan Fox-Decent, "Democratizing Common Law Constitutionalism" (2010) 55:3 McGill LJ 491 (description of a democratic and relational conception of the rule of law).

"Government's Abortion Policy Remains Elusive," The Guardian (8 November 2014), online: $<$ www.theguardian.pe.ca/Opinion/Editorials/2014-11-08/article-3932462/Government\%26rsquo\%3Bsabortion-policy-remains-elusive/1>.

36 Kerry Campbell, "In Depth: No Legal Barrier to Abortion on P.E.I.," CBC News (23 November 2011), online: $<$ www.cbc.ca/news/canada/prince-edward-island/no-legal-barrier-to-abortion-on-p-e-i-1.1012 249> [Campbell, "In Depth"]. In 2010, Health PEI was established as a Crown corporation to administer the provision and delivery of health services in the province, and remains accountable to and under the direction of the Minister of Health and Wellness in its work: Health Services Act, supra note 31, ss 6(1), 12(2).

Campbell, "In Depth," ibid.

Ibid. See Health PEI, "Abortion Services," supra note 6. 
As a rule of law principle, transparency speaks to the importance of law being known. ${ }^{39}$ Where the basis for government action, let alone the action itself, is unknown, people cannot know where they stand in relation to the state and its exercise of power. The threat to the constitutional order comes from the insecurity of these conditions. When no one knows whether or what government action has been taken, there is a true capacity for absolute power. ${ }^{40}$ One of the first requirements of the rule of law is thus an obligation on government to be explicit in its exercises of public power.

The Prince Edward Island abortion policy was visible only as the aggregate of unpublicized, even sometimes unwritten, administrative agreements, policies, and directions, made over the course of decades, and was therefore much less visible than the oppressive structures of the former criminal abortion law. One of the first tasks that AAN PEI counsel undertook was to assemble these materials. ${ }^{41}$ Based on duly enacted regulations, along with responses to freedom of information requests, they reconstructed and rendered visible the elaborate state administration of abortion in Prince Edward Island, showing how the government was deeply implicated in the restricted availability of safe and local abortion services. $^{42}$

At the centre of the abortion policy, AAN PEI placed a 1988 non-binding resolution of the provincial Liberal government, passed immediately following Morgentaler. ${ }^{43}$ Its text reads:

WHEREAS the great majority of the people of Prince Edward Island believe that life begins at conception and any policy that permits abortion is unacceptable;

AND WHEREAS the great majority of Islanders demand that their elected officials show leadership on this very important issue and demonstrate the political will to protect the unborn fetus.

THEREFORE BE IT RESOLVED that the Legislative Assembly of Prince Edward Island [opposes] the performing of abortions. ${ }^{44}$

The resolution, perhaps the clearest statement of government intention, was not exceptional for its time. Even before the Supreme Court struck down the criminal abortion

The Supreme Court of Canada has described the rule of law as a sense of orderliness, including by subjection to known legal rules: Reference re Manitoba Language Rights, [1985] 1 SCR 721 at 750 [Manitoba Language Reference], citing Reference re Resolution to Amend the Constitution, [1985] 1 SCR 753 at 806 .

Mary Liston, "Governments in Miniature: The Rule of Law in the Administrative State" in CM Flood and L Sossin, eds, Administrative Law in Context (Toronto: Edmond Montgomery, 2008) 77 [Liston, "Governments in Minature"] ("[1] aws must be promulgated and public because secret laws undermine legality and frustrate the citizen's ability to know where he or she stands in relation to a system of rights, benefit distribution, and/or enforcement and punishment" at 82). Health PEI for administrative documents, agreements, and correspondence relating to "therapeutic abortion" or the "termination of pregnancy" [on file with author].

42 AAN PEI (Draft Notice of Application), supra note 7 at paras 20-51.

$43 \quad$ "Resolution 17," supra note 5.

$44 \quad$ Ibid at 90-91. 
law, many provincial governments sought to block or limit abortion provision within their borders. The same was true of Prince Edward Island. Under the criminal law, abortion services could only be lawfully provided in accredited or approved hospitals and if approved by a committee as necessary to protect the life or health of the woman. ${ }^{45}$ A burgeoning prolife movement in Prince Edward Island used this bureaucratic structure of the law, with the acquiescence of the state, to effectively cease the provision of lawful services on the Island. ${ }^{46}$ By the mid-1970s, activists occupied hospital boards which then set up rigid approval guidelines, quotas, and other requirements leading to the complete withdrawal of services. A hospital committee last approved an abortion on the Island in 1982, and no hospital committee was operating in the province by $1986 .{ }^{47}$ This history reveals the way in which private and public power collude to limit access. While citizen voting on hospital boards, for example, is far removed from any traditional notion of state action, Lessard has argued that by refusing to interfere and acceding to this private control, government was implicated in the withdrawal of hospital services from the Island. This history thus raises questions about the government's simple claim to market forces in explaining the lack of local services on the Island.

State restrictions on abortion access were more direct in the considerable discretion that provinces enjoyed under the criminal law to designate facilities as "accredited" or "approved" hospitals, where committees could be established and abortions lawfully performed. ${ }^{48}$ To evade obstructive hospital boards, which were eliminating committees and shutting down services across the country, abortion rights activists lobbied provincial governments to accredit or approve free-standing clinics as hospital facilities for the lawful provision of services. ${ }^{49}$ In 1985, when the Prince Edward Island chapter of the Canadian Abortion Rights Action League petitioned then Minister of Health Albert Fogarty to support clinic-based services on this basis, they were informed that the Minister "would not in any way be willing to consider [that] as a possibility." 50

This history shows that the aspiration for an abortion-free Island did not start with the 1988 legislative resolution. Issued in response to Morgentaler, the resolution reaffirmed a commitment to maintain the status quo in a new context of decriminalization. Nearly all provinces in the country enacted some regulation to prevent decriminalization from

Katrina Ackerman, "In Defence of Reason: Religion, Science and the Prince Edward Island AntiAbortion Movement, 1969-1988" (2014) 31:2 Can Bull Medical History 117 at 123, 129. See generally Katrina Ackerman, A Region at Odds: Abortion Politics in the Maritime Provinces, 1969-1988 (PhD Dissertation, University of Waterloo, 2015), online: <https://uwspace.uwaterloo.ca/handle/10012/ 9777? show=full $>$ [Ackerman, A Region at Odds].

Ackerman, A Region at Odds, ibid at 89.

Criminal Code, supra note 45, s 251.

In the 1980s, for example, the Ontario Coalition for Abortion Clinics looked to abortion provision in community-based health centres in Quebec, and modeled their abortion access campaign to achieve the same end. Carolyn Egan, "Twenty-Five Years On: How We Won Abortion Rights," rabble.ca (23 January 2013), online: $<$ rabble.ca/news/2013/01/twenty-five-years-how-we-won-abortion-rights $>$. See also Patricia Antonyshyn, B Lee \& Alex Merrill, "Marching for Women's Lives: The Campaign for Free-Standing Abortion Clinics in Ontario" in Frank Cunningham et al, eds, Social Movements/Social Change: The Politics and Practice of Organizing (Toronto: Between the Lines, in collaboration with the Society for Socialist Studies, 1988) at 130.

50 Ackerman, A Region at Odds, supra note 46 at 188, citing "New Group Support Abortions," The Guardian (21 February 1985) and Katrina Ackerman, "Province's Position Remains Unchanged Despite Petition from Pro-Choice Group," The Guardian (9 May 1985). 
becoming liberalization, another market intervention. ${ }^{51}$ This onslaught of provincial regulation, Ian Urquhart argued, showed how federalism tempers the substantive impact of Charter review, by allowing one level of government to introduce regulatory substitutes for another's unconstitutional initiatives, diluting or delaying the intended policy outcome. ${ }^{52}$

The Prince Edward Island government followed many of its counterparts in creating a hostile funding environment to stave off free-standing clinics from opening in the province. In 1993, Dr. Morgentaler legally challenged these funding restrictions, but lost at the Court of Appeal. ${ }^{53}$ After expressing an intention to open an abortion clinic in the province, Morgentaler inquired directly about available public funding for these services. He was told that per an unwritten policy, the government funds abortion services only if deemed medically required by a committee and performed at an approved hospital, the very same authorization requirements of the former criminal law. ${ }^{54}$ Morgentaler challenged the policy on the grounds that it was unwritten and enacted without legal authority. Mere days before his application was heard, the Prince Edward Island government turned the informal policy into duly enacted regulation. ${ }^{55}$ Morgentaler amended his claim and challenged the new regulation on its substantive restrictions, arguing that the government's policy 'effectively prohibits abortions from taking place within Prince Edward Island.... [The funding] conditions on their face contain all of the trappings and have the practical effect of inhibiting or thwarting access to legal therapeutic abortion." ${ }^{56}$ The Court of Appeal upheld the funding restrictions, which remained unchanged until June 2016, when the government announced a regulatory reform. Under new regulations enacted pursuant to the Health Services Payment Act ${ }^{57}$ local abortion services were eligible for public funding if provided in a hospital, but no longer needed to be approved as medically required. ${ }^{58}$

Although there was a code for "therapeutic abortion" in the provincial tariff of fees, which sets reimbursement rates for physician services, at the time AAN PEI began its challenge,

51 See Joanna N Erdman, "In the Back Alleys of Health Care: Abortion, Equality, and Community in Canada" (2007) 56:4 Emory LJ 1093 at 1094.

52 Ian T Urquhart, "Federalism, Ideology, and Charter Review: Alberta's Response to Morgentaler" (1989) 4 CJLS 157 at 161.

$53 \quad$ Morgentaler $v$ Prince Edward Island (Minister of Health and Social Services) (1995), 126 Nfld \& PEIR 240 (PEI SC (TD)) [Morgentaler v PEI], rev'd (1996), 144 Nfld \& PEIR 263 (PEI SC (AD)) [Morgentaler v PEI CA].

$54 \quad$ Morgentaler $v$ PEI, ibid at para 4.

$55 \quad$ Health Services Payment Act Regulations, PEI Reg EC453/96, s 1(c)(iv) [HSPA Regulations]: "basic health services" insured under the Health Services Payment Act, RSPEI 1988, c H-2 include "services provided in respect of termination of pregnancy performed in a hospital when the condition of the patient is such that the service is determined by the Minister to be medically required." Section 6(1)(c) of the HSPA Regulations (ibid) delegates the Minister's decision on whether termination of pregnancy is "medically required" to an advisory committee, composed of three to five appointed doctors.

Morgentaler v PEI, supra note 53 paras 67, 72.

Supra note 55.

Kerry Campbell, “Abortions No Longer Need to Be 'Medically Required' for P.E.I. to Pay for Them," CBC News (9 June 2016), online: $<$ www.cbc.ca/news/canada/prince-edward-island/abortions-no-longerneed-to-be-medically-required-for-p-e-i-to-pay-for-them-1.3623765>. After this regulatory change, an application for judicial review was filed arguing that the abortion policy was unlawful precisely because it now authorized funding for out-of-province abortion services without prior approval, namely physician referral or certification of medical need. In July 2016, the Prince Edward Island Supreme Court dismissed the application. See "P.E.I. Man Wants Province to Stop Funding Out-of-Province Abortions" CBC News (18 February 2016), online: <www.cbc.ca/news/canada/prince-edward-island/peiabortion-judicial-review-1.3453608>; Steve Bruce, "P.E.I. Supreme Court Will Not Proceed With Abortion Challenge" CBC News (18 July 2016), online: <www.cbc.ca/news/canada/prince-edwardisland/pei-abortion-supreme-court-judicial-review-standing-1.3683854>. 
no claims had ever been filed under this code according to Health PEI. ${ }^{59}$ The Canadian Institute for Health Information also consistently reported zero abortions for Prince Edward Island in its Therapeutic Abortion Database on the explanation that no hospital or clinic on the Island provides the service. ${ }^{60}$ On paper, Prince Edward Island appeared the life sanctuary to which it has aspired, largely by sending its abortions, and the women who seek them, to the clinics and hospitals of other Canadian provinces. ${ }^{61}$

The Prince Edward Island abortion policy also included the terms and conditions of funding for these out-of-province services. Since 1995, under a reciprocal billing agreement, the government has covered physician and hospital fees for abortion services provided to Island women at the Queen Elizabeth II Hospital (QEII) in Halifax, Nova Scotia. All incidental and travel expenses were paid out-of-pocket. It was not until December 2011, however, that Health PEI released any public information about the availability, terms and conditions of this funding. ${ }^{62}$ Unlike local services, abortion services at the QEII qualify for public funding only on a Prince Edward Island physician's referral of medical need and prior administrative approval. These requirements were unaffected by the reform in funding regulation because they were set by a separate, unpublished policy related to an out-ofprovince funding program for non-emergency health services. ${ }^{63}$ This policy states that "[s]ince 1982 abortion services have not been available in Prince Edward Island. P.E.I. residents are referred out-of-province for abortion services." ${ }^{\prime 64}$ It is one of the only written acknowledgments that out-of-province travel was part of the province's regulatory scheme. Its phrasing, however, suggests that residents are referred out-of-province because there were no local services, not that the province had endeavored for decades to keep the Island abortion-free, including by the referral and funding of services off the Island. In recent years, facing increased public criticism of the policy, the province adopted yet further measures to facilitate out-of-province access. Health PEI contracted with the Maritime Bus company for subsidized travel for low-income patients, improved the quality of public information on its

In response to a Freedom of Information request, Health PEI indicated that no claims have ever been filed under fee code 6010. According to the current fee-for-service contract between the province and the PEI Medical Society, a doctor would be paid \$151 for the service. Kerry Campbell, "Abortion law Q \& A," CBC News (13 January 2012), online: <www.cbc.ca/news/canada/prince-edward-island/ abortion-law-q-a-1.1242368>.

60 Canadian Institute for Health Research, Privacy Impact Assessment of the Therapeutic Abortions Database (CIHI, 2003), online: $<$ https://www.cihi.ca/en/ services tad pia en.pdf $>$ ("“a]bortions are not reported by Prince Edward Island since there are no hospitals or clinics in the province that perform the procedure. The residents of Prince Edward Island are, however, included in the data reported by other provinces" at 7).

61 Canadian hospitals reported having provided 94 Island residents with abortion services in 2014: Canadian Institute for Health Information, Induced Abortions Reported in Canada in 2014 at table 3, online: $<$ https://www.cihi.ca/sites/default/files/document/induced abortion can 2014 en web.xlsx $>$. See Health PEI, “Abortion Services," supra note 6.

63 The 1995 policy was obtained through a Freedom of Information request, as well as revised copies dating from July 2001, July 2007, and July 2013. The policy is not included in or appended to any other policy or agreement regarding provision/payment of health services. Under section 11(3) of the HSPA Regulations, supra note 55, the Minister "may by policy establish requirements concerning prior approval of coverage for non-emergency services rendered out of the province."

64 See Kerry Campbell, “Abortion Access on P.E.I.: What the Province's Current Policy Actually Says," CBC News (1 April 2016), online: <www.cbc.ca/news/canada/prince-edward-island/pei-abortion-policy$1.3516774>$, citing the policy discussed, ibid. 
website, and in 2015, extended public funding for abortion services provided, without local referral, at the Moncton Hospital in New Brunswick. ${ }^{65}$

AAN PEI's reconstruction of a Prince Edward Island abortion policy had a profound effect, not least in leading the government itself, including the Premier in his promise of reform, to admit that the government indeed had a policy on abortion - a reality they had denied for too long. This denial of the policy was deeply insulting to the women who had laboured under its burdens for decades, a disturbing form of disrespect. The political deceit and manipulation in the lack of government transparency about its role in the withdrawal of local hospital services, the obstruction of clinic services, and the funding and referral out-ofprovince to quell criticism and avoid reform, speak to a profound subversion of democratic government. AAN PEI thus made a constitutional claim on government in the very exposure of its abortion policy, by claiming access to information as a constituent element of abortion rights in a democratic tradition.

\section{An Argument From ACCOUntabiLity}

AAN PEI did not alone make the abortion policy central to the legal challenge. Rather, the activists went looking for the policy after the government relied upon it to defend a controversial act of executive discretion: the quashing of a new proposal to bring abortion services to Prince Edward Island. For the first time, publicly and expressly, the government said that on-Island abortion service provision was contrary to public policy.

In 2014, a CBC investigative report revealed that the year before, three physicians had approached the major Prince Edward Island hospitals to express interest in providing abortion services on the Island. ${ }^{66}$ Based on this interest, Dr. Rosemary Henderson, the medical director of the Queen Elizabeth Hospital in Charlottetown, assembled a working group within Health PEI and developed a business plan for the service, which detailed the current state of abortion access for Prince Edward Island women, the operational details for an ambulatory clinic, and its cost savings for patients and government ${ }^{67}$ Immediately before moving the plan forward for approval within Health PEI, Dr. Richard Wedge, now Chief

In 2015, the New Brunswick government eliminated funding restrictions of certified medical need for abortion services in its own public health insurance plan, and abortion was also taken off the excluded services list of the Inter-Provincial Reciprocal Agreement which had required that service costs be billed according to the host province's regulation. Prior to this change, all reciprocal billing arrangements for abortion services were informal, with provinces reimbursing health facilities for services rendered on a case-by-case basis through prior approval. Order in Council, 2014-444 (24 December 2014). See also New Brunswick Office of the Premier, Press Release, "Provincial Governement Rmeoves Barriers to a Women's Right to Choose" (26 November 2014), online: <www2.gnb.ca/content/gnb/en/news/ news release.2014.11.1334.html $>$. See Appendix F of "Reciprocal Billing Agreement," Canadian Institute for Health Information (Ottawa: CIHI, 2015). See also “Abortion Access Made Easier for P.E.I. Women," CBC News (2 June 2015), online: <www.cbc.ca/news/canada/prince-edward-island/abortionaccess-made-easier-for-p-e-i-women-1.3096669>; "Abortions Performed on 49 P.E.I. Women in N.B. Since Direct Phone Line Launched," CBC News (15 December 2015), online: <www.cbc.ca/news/ canada/prince-edward-island/abortion-phone-line-1.3366738>.

66 "Abortion Clinic Working Group Was Convened by Health PEI," CBC News (30 May 2014), online: $<$ www.cbc.ca/news/canada/prince-edward-island/abortion-clinic-working-group-was-convened-byhealth-pei-1.2659470> [CBC News, "Abortion Clinic Working Group"]; “Abortion Service on P.E.I. Would Have Saved Money: Report," CBC News (20 October 2014), online: <www.cbc.ca/news/canada/ prince-edward-island/abortion-service-on-p-e-i-would-have-saved-money-report-1.2803587> [CBC News, "Abortion Service on P.E.I."].

67 Health PEI, "Project Proposal: Business Case, Termination of Pregnancy Service," Executive Sponsor: Dr. Nadeem Dada (3 March 2014) [on file with author]. 
Executive Officer of Health PEI, called Dr. Henderson to say, "[Health PEI] has been explicitly told to cease work on the abortion project." ${ }^{98}$ He later confirmed that then Health Minister Doug Currie issued the direction, "[t]he minister said there's no point in putting more resources into a project ... that's against government policy." ${ }^{69}$ Henderson ignored the instruction. She introduced the business plan for approval before the Provincial Medical Advisory Committee of Health PEI, wanting the record to show that this independent expert advisory body had approved the plan. ${ }^{70}$ Beyond this committee, however, the business plan was never reviewed by the executive level of Health PEI and died within these bureaucratic channels. ${ }^{71}$

The CBC investigative report of these events prompted a government response. Dr. Wedge explained that as "Health PEI, we are required by law to follow government policy ... [and there is] a policy in government that says abortions will not be done on Prince Edward Island." 72 The Health Minister also deferred to policy in defence of his actions, explaining that Health PEI should never have developed the business plan in the first place, given the clear government policy on the issue. ${ }^{73}$ In shutting down the business plan for an abortion service on the Island, Health PEI claimed only to be following government policy. In directing Health PEI to cease development of the business plan, the Health Minister similarly claimed only to be administering government policy. Each invoked the abortion policy as reason, or legal authority, for their executive action in an effort to show these actions were not arbitrary, at least in this way.

The government placed the abortion policy at the centre of public debate, an opportunity AAN PEI seized upon to raise a substantive challenge against it. They argued that whether written or not, the abortion policy was itself arbitrary, that is, without legal authority. This is a classic rule of law challenge to government action, which AAN PEI developed in the first instance in a narrow, positivist way. ${ }^{74}$ They looked to and relied on the express constraints of legislation, namely the Health Services Act, in an effort to hold government accountable to its terms and purposes as an explicit delegation of public power. AAN PEI, however, developed this legalistic argument in a way that embraced the larger constitutional framing of the case.

The abortion policy was invoked not against an individual claim of entitlement, but against a collaborative governance effort to improve provision of health care in the province. More than simply jeopardizing access to a discrete service, the government's quashing of the business plan raised a question about the administration of the public health care system and the exercise of public power within it. The government's action showed that administration

$68 \quad$ CBC News, “Abortion Service on P.E.I.,” supra note 66.

69 Ibid. The Minister was authorized to issue such orders, and Health PEI obligated to follow such orders pursuant to sections 3(2)(e) and 12(2) of the Health Services Act, supra note 31.

70 Ibid. Health PEI, Medical Staff Bylaws (Charlottetown: Health PEI, February 2011), ss 13-17, online:

<www.healthpei.ca/photos/ original/hpei_medstaffby.pdf>, ss 13-17.

CBC News, "Abortion Clinic Working Group," supra note 66.

CBC News, "Abortion Service on P.E.I.," supra note 66.

"Government's Abortion Policy Remains Elusive," supra note 35. See also “P.E.I. Abortion Policy Not Led by Health Minister," CBC News (7 November 2014), online: <www.cbc.ca/news/canada/princeedward-island/p-e-i-abortion-policy-not-led-by-health-minister-1.2827174>.

74 Manitoba Language Reference, supra note 39 at 748-49. See also Liston, "Governments in Minature," supra note 40 ("[a]ny power that was not authorized by Parliament, or had acted beyond the powers delegated to it, would be considered ultra vires" at 81). 
of the system was not open to the experiences and needs of those who work within it and to those who depend upon it. The quashing of the business plan represented a crisis of accountability. This crisis was more marked because the devolution of power to Health PEI, at arm's length from government, was designed precisely to protect against it. ${ }^{75}$ In a devolved administration, the government defines the values of the health care system and sets policies derived from those values, but otherwise gives up its hold on the management of the system, allowing those who deliver health care to determine how best to do so. ${ }^{76}$ Devolution promises more meaningful accountability not only by opening space for democratic engagement, but also by rationalizing health care management through independent, transparent, and evidence-based decision-making. ${ }^{77}$

A significant accountability tool in this regard is law, or more particularly, legislation. Devolution requires a detailed legislative framework to separate and distribute governance and management powers. In Prince Edward Island, the Health Services Act not only delegates power to Health PEI, but constrains that power by an overt statement of the values and goals by which health care is to be governed and managed in the province. ${ }^{78}$ The Minister of Health is also bound by these principles and goals in an effort to create coherence in the system. The Health Services Act formally achieves this coherence by obligating the Minister of Health and Health PEI to govern and manage health care respectively in accordance with the Provincial Health Plan. ${ }^{79}$ This ministerial document sets out the health services that government is to provide in the province, and the principles, goals, and objectives that are to inform this provision. ${ }^{80}$ By the terms of this plan, health care is to be delivered through a single, integrated system grounded in evidence-based decision-making, and focused on improving health, enhancing access, and emphasizing services that can appropriately and safely be provided locally. ${ }^{81}$ The plan promises that the public can expect their health system to be governed in accordance with the goals of equity and efficiency, providing fair allocation and timely access to services based on need, and using health care resources as efficiently as possible. The overall objective of the plan is to meet Islanders' "needs in the most appropriate setting, by the most appropriate provider and in the most cost effective manner." 82

Liston, "Witnessing Arbitrariness," supra note 28 ("Montesquieu's most famous institutional remedy for the risks of arbitrariness: to separate and distribute power among several institutions and corresponding persons so that no institution or official possesses an effective monopoly or stranglehold" at 696).

76 Colleen M Flood, Duncan Sinclair \& Joanna Erdman, "Steering and Rowing in Health Care: The Devolution Option?" (2004) 30:1 Queen's LJ 156 at 172.

77 Ibid at 173-74. See also Lester M Salamon, "The New Governance and the Tools of Public Action: An Introduction" (2001) 28:5 Fordham Urb LJ 1611.

78 Health Services Act, supra note 31.

79 The Minister of Health is required to "ensure the provision of health services in the province in accordance with the provincial health plan": Health Services Act, supra note 31, s 2(2) [emphasis added]. Health PEI is obligated to "provide or provide for the delivery of health services in accordance with the provincial health plan": ibid, s 12(1)(a) [emphasis added].

80 Ibid, s 3(1). Despite its central role in the administration of the Prince Edward Island health care system, the Provincial Health Plan is not publicly available, and was again, obtained only by a Freedom of Information request. A copy of the 2010 Provincial Health Plan was obtained, and no subsequent amendments to the plan were discovered: FOI 1690-20-04 15 (27 April 2015) [on file with author].

81 Provincial Health Plan, ibid at iii-iv. These goals are repeated in Health PEI, Strategic Plan 2013-2016 (Charlottetown: Health PEI, March 2013), online: <www.gov.pe.ca/photos/original/hpei_stratpl_16. pdf $>$.

82 Provincial Health Plan, ibid at iii. 
AAN PEI used this legislative scheme to argue that the abortion policy, and all administrative action to enforce it, was inconsistent with the Health Services Act and was therefore invalid. ${ }^{83}$ In more specific terms, they showed through factual inquiry how the provision of abortion services through referral to off-Island hospitals is inconsistent with, if not contrary to, the principles, goals, and objectives of the Provincial Health Plan.

In the press, the government defended the abortion policy as part of a larger regionalization strategy, claiming there are a number of services that are not offered on the Island, and which Islanders must travel to neighbouring provinces to receive - abortion is simply one of those services. ${ }^{84}$ The government cited heart surgery, cancer treatment, hip replacements, and pediatric services as other examples. ${ }^{85}$ AAN PEI acknowledged that such a class of services indeed exists under the Provincial Health Plan and that Islanders are referred out-of-province for hospital services, but only for highly specialized procedures. ${ }^{86}$ The out-of-province referral policy, to which abortion is subject, similarly emphasizes this limitation, authorizing payment for services only where they are unavailable locally — all examples of which again are highly specialized treatments (such as neurosurgery, cardiac surgery, and neonatology). ${ }^{87}$

Abortion, AAN PEI argued, particularly early in pregnancy, cannot reasonably be classified as a highly specialized service, as it requires no advanced technical skill or specialized equipment. ${ }^{88}$ The World Health Organization advises that many evidence-based interventions for safe abortion can be provided on an outpatient basis at the primary care level. ${ }^{89}$ This is precisely what the business plan recommended: the provision of abortion care on a same-day, outpatient basis in the ambulatory care centre of the Queen Elizabeth Hospital. In fact, abortion services were once provided at the Queen Elizabeth Hospital, in its former incarnation as the Prince Edward Island Hospital. These services were cancelled, however, as a condition of the hospital merging with the Catholic-affiliated Charlottetown Hospital, in other words, for reasons related to neither medical need nor cost. ${ }^{90}$ In December 2015, when Health PEI announced a review of the province's ambulatory care services, it revealed no plans to reassess the provision of abortion services, which would have at least provided some evidence for the government's actions. ${ }^{91}$

AAN PEI (Draft Notice of Application), supra note 7 at paras 64-77.

CBC News, "No Need for Local Abortion Services," supra note 21. See also "Lack of Abortion Access Fuels Risks to Women, Says Report," CBC News (28 January 2014), online: <www.cbc.ca/news/ canada/prince-edward-island/lack-of-abortion-access-fuels-risks-to-women-says-report-1.2513673> [CBC News, "Lack of Abortion Access"].

Tamsin McMahon, "P.E.I. Abortion Ban Challenged by New Pro-Choice Movement," National Post (16 November 2011), online: <news.nationalpost.com/2011/11/16/p-e-i-abortion-ban-challenged-bynew-pro-choice-movement/>.

AAN PEI (Draft Notice of Application), supra note 7 at paras 70-72. See Provincial Health Plan, supra note 77 at 31 .

Health PEI, Criteria for Payment Out-of-Province Referrals, Appendix to the Master Agreement negotiated between Health PEI, the PEI government and the Medical Society of PEI [on file with author].

AAN PEI (Draft Notice of Application), supra note 7 at para 71.

World Health Organization, Safe Abortion: Technical and Policy Guidance for Health Systems, 2nd ed (Geneva: WHO, 2012) at 67. See also World Health Organization, Health Worker Roles in Providing Safe Abortion Care and Post-Abortion Contraception (Geneva: WHO, 2015) at 3.

Ackerman, A Region at Odds, supra note 46 at 76.

Kerry Campbell, "P.E.I. to Review Ambulatory Care Services," CBC News (15 December 2015), online: $<$ www.cbc.ca/news/canada/prince-edward-island/pei-ambulatory-care-review-1.3365008 $>$. 
Based on these facts, AAN PEI argued that the abortion policy is inconsistent with the principles, goals, and objectives of the Provincial Health Plan. ${ }^{92}$ Abortion services are not delivered through a single, integrated system. Rather, services are administered by various regulations and policies, and funded in three provinces under three different sets of conditions. This does not account moreover for the fact that many Islanders seek abortion care entirely outside of this system. The abortion policy is not evidence-based, focused on enhancing access, equity, and efficiency. Rather, the government has adhered to the policy against evidence-based, cost-savings proposals in categorical opposition to reform, suggesting that its actions are motivated by reasons outside the legislative scheme. ${ }^{93}$

AAN PEI attacked the abortion policy as an arbitrary exercise of public power, being inconsistent with the Health Services Act and therefore without legal authority. ${ }^{94}$ By running this argument, AAN PEI countered the government's public claim to enjoy absolute discretion in the provision and funding of abortion services. Rather by the explicit terms of statute, the Ministry of Health is obligated to govern and Health PEI is obligated to manage the health care system, only for the purposes for which their public power is conferred. By relying on the legislative framework, AAN PEI claimed abortion rights not against state intervention, but as a means to enforce that intervention, a claim on the state and its protections. Contrary to the paradigmatic abortion rights claim, in this case, democratic law does not offend reproductive liberty, security, and equality, but rather secures them. AAN PEI endeavoured to enforce the democratic promise of legislation, namely that the public power it delegates to government will be used for the benefits of the persons subject to it. ${ }^{95}$

Nonetheless there are critiques of a legalistic rule of law argument. First, rarely is the content of legislation so precise as to admit to a single, correct interpretation of the constraints it sets on public power. The duties of the government under the Health Services Act are expressed in broad terms and leave government with much discretion in how to pursue its ends. Dr. Morgentaler failed in his challenge against the Prince Edward Island funding regulations for precisely this reason. He argued the regulations were inconsistent with the objective of the governing legislation, the Health Services Payment Act, ${ }^{96}$ which he described as the universal and comprehensive funding of basic health services. The Court of Appeal, however, found in the Act a broad discretion for government to decide what health services to cover and under what conditions. ${ }^{97}$ This was not an unusual outcome for its time. Most provincial funding restrictions enacted after Morgentaler were legally challenged and resolved on similar grounds. ${ }^{98}$ Even when these challenges were successful, many of the victories were short lived. This is a second critique of a positivist rule of law argument. The government can always amend legislation, and so provide a lawful way to achieve the same policy end. ${ }^{99}$ The rule of law is maintained to the extent that the administration does not act

AAN PEI (Draft Notice of Application), supra note 7 at para 68.

Ibid at para 84 .

Ibid at para 77.

Dyzenhaus, supra note 29 ("legislation itself provides protection in a system of parliamentary sovereignty ... [and that] protection is inherently demoratic" at 496).

Health Services Payment Act, supra note 55.

Morgentaler $v$ PEI CA, supra note 53 at paras 8-11.

Erdman, supra note 51 at 1105 . See also Rachael Johnstone \& Emmett Macfarlane, "Public Policy, Rights, and Abortion Access in Canada" (2015) 51 Intl J Can Studies 97 at 104.

See e.g. Lexogest Inc v Manitoba (Attorney-General) (1993), 101 DLR (4th) 523 [Lexogest]. 
outside the explicit constraints Parliament has set in legislation. As long as the government stays within these limits, they may act as they please. ${ }^{100}$

This leads to a deeper concern about the proper purpose and ends for which public power can be used regardless of legislative warrant. For AAN PEI, the true injustice of the abortion policy was its effect on the health and lives of women subject to it, and the government's seeming indifference to this effect. Whatever discretion the government enjoys in health care governance, by whatever grant of legislative authority, it cannot extend into utter indifference. Such disregard damages the normative relationship between citizen and state, and so reaches a constitutional order of injustice.

\section{An Argument From Constitutional Justice}

In a third rule of law argument, AAN PEI returned to the idea that any grant of public power always implies good faith in the exercise of that power. This obligation, however, is not limited to the express terms of statute, but extends to substantive values inherent in the constitutional order of democratic government. In the Secession Reference, the Supreme Court drew reference to this thicker account of the rule of law, stating that:

[A] system of government cannot survive through adherence to law alone.... Our law's claim to legitimacy also rests on an appeal to moral values, many of which are imbedded in our constitutional structure. It would be a grave mistake to equate legitimacy with the "sovereign will" or majority rule alone, to the exclusion of other constitutional values. ${ }^{101}$

AAN PEI challenged the abortion policy in this tradition of constitutional legality, that is, drawing on values that are prior to or transcend ordinary politics and that reside in a larger constitutional morality. ${ }^{102}$ To do so they relied on two legal sources: the Canada Health Act ${ }^{103}$ and the Charter. ${ }^{104}$ These national sources of law brought a federalism dynamic into the public abortion debate, an especially strong discourse under the Canada Health Act and the constitutional values of Medicare.

The Canada Health Act is a federal spending statute that establishes national criteria provincial health insurance plans must satisfy to qualify for full federal contribution. ${ }^{105}$ In this sense, Medicare is neither a legal obligation of government nor a legal right of citizens. Nonetheless its promise of a health care system based on need and not ability to pay is regarded with national pride, its social democratic values strongly tied to an understanding of Canadian citizenship. ${ }^{106}$

Dyzenhaus, supra note 29 ("the rule of law is substantively empty.... [I]f the legislature has delegated authority to an official, the only controls on the official are those controls explicitly stated in the legislation.... [A]s long as he stays within the limits of his authority he can act as he pleases" at 126). Secession Reference, supra note 28 at paras 67-68.

See discussion of the deep structure of the rule of law and constitutional morality in Dyzenhaus, supra note 29.

Canada Health Act, RSC 1985, c C-6.

Charter, supra note 8.

Canada Health Act, supra note 103, ss 2, 7.

Antonia Maioni. "Citizenship and Health Care in Canada" (2010) 42 Intl J Can Studies 225. See also Roy J Romanow, Building on Values: The Future of Health Care in Canada (Saskatoon: Commission on the Future of Health Care in Canada, 2002), xvi. 
Abortion rights activists across the Atlantic region advocated for abortion policy reform on the basis of the Canada Health Act, less in its formal content and more in its spirit and values. They used Medicare to challenge a deeply ingrained sense of Maritime exceptionalism - that residents of this region, being too small or too poor, cannot expect the same entitlements enjoyed by Canadians elsewhere. ${ }^{107}$ In launching their legal challenge, AAN PEI expressly called out this regional disparity in national entitlement: "Every other province provides safe legal access to abortion. Only PEI refuses to do so. It is time for our equality rights to matter."108

Yet the status of abortion under the Canada Health Act has been the subject of long controversy, namely the question of whether abortion is a medically necessary service, and thus subject to the terms of the statute. After Morgentaler lost his legal challenge to the Prince Edward Island funding restrictions, he lobbied the federal Minister of Health to enforce the Canada Health Act against the province, and to withhold funding until the province reformed its policy. ${ }^{109}$ There was precedent for such federal intervention. In the 1990s, federal Health Minister Diane Marleau wrote to all provinces explaining that their failure to cover private clinic fees for medically necessary services, including abortion, contravened the Canada Health Act and that unless provinces funded these services, they would face financial penalty. ${ }^{110}$ In 2001, federal Health Minister Allan Rock specifically warned the Prince Edward Island government that failure to fund clinic abortion services constituted a violation of the Canada Health Act, and threatened to withhold transfer payments unless abortion was treated like all other medically insured services, regardless of where they were performed. ${ }^{111}$ After AAN PEI launched their challenge, Federal Health Minister Jane Philipott affirmed that women "should have access to reproductive health services, no matter where they live in our country," but refrained from taking any enforcement action under the Canada Health Act. ${ }^{12}$

Interestingly the Canada Health Act ultimately figured much more prominently in the Prince Edward Island government's defence of the abortion policy than in the formal legal argument of AAN PEI. The government, for example, made repeated claims of legal compliance with the Canada Health Act, the designation of a health service as an insured

Joanne H Wright. "What the New Liberal Government Should Know About Reproductive Freedom and Justice in New Brunswick" (2014) 5 JNB Studies, online: <https://journals.lib.unb.ca/index.php/ JNBS/article/view/22334/25933>; McMahon, supra note 85; “Abortion Rights Lobby Launches on P.E.I.," CBC News (8 November 2011), online: <www.cbc.ca/news/canada/prince-edward-island/ abortion-rights-lobby-launches-on-p-e-i-1.1019589>.

LEAF, “Abortion Access Now," supra note 3.

The Prince Edward Island Court of Appeal upheld the public funding restrictions on abortion services in part because Health Canada had never expressed any concern or otherwise taken any action against the province to suggest that its funding policy was in contravention of the Canada Health Act. See Morgentaler $v$ PEI CA, supra note 53 at paras $8-11$.

Letter from Diane Marleau, Minister of National Health and Welfare to provincial and territorial Ministers of Health (6 January 1995), online: Abortion Rights Coalition of Canada <http://arcccdac.ca/backrounders/HC-letter-Jan1995.pdf $>$. See also Canada, Minister of National Health and Welfare, "Statement by the Honourable Diane Marleau" (16 October 1995), online: Abortion Rights Coalition of Canada <www.arcc-cdac.ca/backrounders/HC-letter-Oct1995.pdf $>$. See Health Canada, "Canada Health Act Annual Report 2014-2015, (Ottawa: Health Canada, 2015), online: <www.hcsc.gc.ca/hcs-sss/alt formats/pdf/pubs/cha-ics/2015-cha-lcs-ar-ra-eng.pdf $>$ at 13-15.

Laura Eggertson, "Ā bortion Services in Canada: A Patchwork Quilt with Many Holes" (2001) 164:6 CMAJ 847.

Anna Mehler Paperny, "Health Minister 'Will be Checking' on Provinces' Abortion Access Plans," Global News (23 February 2016), online: <globalnews.ca/news/2521879/health-minister-will-bechecking-on-provinces-abortion-access-plans/>. 
service being solely within provincial discretion. ${ }^{113}$ Even on yielding to the constitutional challenge, Premier MacLauchlan denied the Canada Health Act any legal force, repeating that "government has the right to decide what health-care services are available under the Canada Health Act. That wasn't the basis on which we formed the view that a change was in order." 114

The history of abortion policy under the Canada Health Act reveals federalism as a key dynamic in constitutional legality, even apart from judicial review. It again shows how federalism may allow one level of government to temper the unconstitutional initiatives of another. Yet, to use the national standards of the Canada Health Act to exact social benefits from the strained public programs of an economically and political marginalized province is a complex proposition, too easily portrayed as action against the collective well-being of Islanders. This is perhaps why AAN PEI refrained from making any argument on the Canada Health Act in its formal application, electing rather to draw on the values of provincial law, a deliberate act to hold government accountable to standards imposed not by Ottawa, but promised to Islanders by their own government. The Premier's insistence on legal compliance with the Canada Health Act, and its otherwise irrelevance to the abortion policy, also raises a question about the survival of common law constitutionalism in Canada, the extent to which governments feel compelled by any larger political morality that should or ought to govern the provision or delivery of health care services in this country apart from the express terms of the Constitution. ${ }^{115}$ Given these concerns, AAN PEI turned to the express text and legal constraints of the Charter.

When Premier MacLauchlan announced his government's intention to reform the abortion policy, he cited women's Charter rights to security of the person and equality as obligating government to provide timely health care without discrimination. This is a revealing statement about the form of AAN PEI's Charter arguments. They claimed abortion rights as entitlements to state provision of safe and local health care, and did so moreover despite a strong constitutional precedent that admits to no free-standing rights to health care. ${ }^{116}$

The success of their claims relied on a construction of abortion rights under the Charter as democratic rights, that is, as claims on the state to build its institutions in the collective interest. Jackman has ably written on the capacity of Charter rights to serve this function in the health care context. ${ }^{117}$ AAN PEI claimed Charter rights not only as an adjudicative recourse of last resort to secure safe and local abortion access, but as a prospective governing framework to ensure that abortion policy is informed by values of fundamental justice and substantive equality. This is evident in the way AAN PEI structured their legal arguments under sections 7 and 15 of the Charter. ${ }^{118}$

113 CBC News, “Abortion Service on P.E.I.," supra note 66.

114 Fine, supra note 9.

115 See limitations on rule of law argument in $R v$ Imperial Tobacco Canada Ltd, 2011 SCC 42, [2011] 3 SCR 45 at para 59. See also Liston, "Governments in Minature," supra note 40 at 93-97.

See supra note 18 .

Jackman, supra note 20 at 424-25.

AAN PEI also ran arguments under section 12 of Charter, but these arguments did not play a significant part in the public debates and are therefore not addressed by this article. See AAN PEI (Draft Notice of Application), supra note 7 at paras 146-56. 
Section 7 of the Charter guarantees everyone "the right to life, liberty and security of the person and the right not to be deprived thereof except in accordance with the principles of fundamental justice." 119 In Morgentaler, a majority of the Supreme Court found the criminal abortion law in violation of this right because its administrative requirements endangered women's health by delaying or denying access to care. ${ }^{120}$ This finding was based on empirical facts about how the law worked in practice. ${ }^{121}$ The Supreme Court, in other words, refused to read the effects of the law from its mere words or intentions. AAN PEI advanced a similar argument, namely that the Prince Edward Island abortion policy in practice endangered the health of Island women.

The argument was largely based on a 2014 study, led by AAN PEI founding member MacQuarrie, of women's first person accounts in seeking and accessing abortion services under the policy. ${ }^{122}$ Other testimonial accounts of women's experiences followed the release of the study. ${ }^{123}$ Beyond revealing the unanticipated effects of the policy, these collected accounts also revealed abortion as a shared experience within the community, a matter thus of both public and private interest. Moreover, this privileging of women's first person accounts is a significant constitutional intervention in itself, suggesting that the perspectives and experiences of those affected by a policy matter to its legitimacy. ${ }^{124}$

The MacQuarrie study revealed that the abortion policy created significant risk and harm. First, due to the lack of transparency of the policy and its complex administration, women and physicians in the province laboured under a significant lack of information, even misinformation, about the terms and conditions of abortion provision. ${ }^{125}$ Abortion access was described as akin to "so many other things on the island: hard to do unless you know someone who knows someone, who can help you out." ${ }^{26}$ This was especially true of local

Charter, supra note 8 , s 7 .

Morgentaler, supra note 4 at 56-63, 91-101.

Ibid at 56. See Canada, Department of Justice, Report of the Committee on the Operation of the Abortion Law (Ottawa: Minister of Supply and Services Canada, 1977) at 3, 17, 27-35 [Badgley Report]. The mandate of the Committee was to "conduct a study to determine whether the procedure provided in the Criminal Code for obtaining therapeutic abortions is operating equitably across Canada": Morgentaler, ibid at 65, citing Orders-in-Council PC 1975-2305, 1975-2306, and 1975-2307 of 29 September 1975 and its terms of reference.

Colleen MacQuarrie, Jo-Ann MacDonald \& Cathrine Chambers, Trials and Trails of Accessing Abortion in PEI: Reporting on the Impact of PEI's Abortion Policies (Charlottetown: University of Prince Edward Island, 2014), online: <projects.upei.ca/cmacquarrie/files/2014/01/trials_and_trails_final.pdf $>$.

See The Sovereign Uterus, (blog), online: <https://thesovereignuterus.wordpress.com/> (containing anonymous narrative accounts of women's experiences in navigating the regulatory system); Teresa Wright, "P.E.I. Women Share Harrowing Abortion Stories," The Guardian (30 May 2015), online: $<$ www.theguardian.pe.ca/News/Local/2015-05-30/article-4164010/P.E.I.-women-share-harrowingabortion-stories/1> [Wright, "Women Share"]; Anna Mehler Paperny, "Your Stories: Navigating Canada's Abortion Provider Patchwork," Global News (5 January 2016), online: < globalnews.ca/news/ 2426906/your-stories-navigating-canadas-abortion-provider-patchwork/>.

In Canada (Attorney General) v Bedford, 2013 SCC 72, [2013] 3 SCR 1101 [Bedford], for example, the Courts similarly relied on those with first hand knowledge of the criminal prostitution laws and its effects, namely sex workers, to strike down these laws as unconstitutional. See also Emily van der Meulen, Elya M Durisin \& Victoria Love, "Introduction" in Emily van der Meulen, Elya M Durisin \& Victoria Love, eds, Selling Sex: Experience, Advocacy, and Research on Sex Work in Canada (Vancouver: UBC Press, 2013) 1 at 13; Jacqueline Lewis, Frances M Shaver \& Eleanor MatickaTyndale, "Going 'round Again: The Persistence of Prostitution-Related Stigma" in van der Meulen, Durisin \& Love (ibid) 198 at 200-201; Alan Young, "Afterword" in van der Meulen, Durisin \& Love (ibid) 323 at $324-25$.

MacQuarrie, MacDonald \& Chambers, supra note 122 at 8, 10-11, 16.

Kate McKenna, "Harrowing Experiences of Medical Abortions on Canada's Prince Edward Island Renews Criticism," VICE Magazine (26 May 2015), online: <https://news.vice.com/article/harrowingexperiences-of-medical-abortions-on-canadas-prince-edward-island-renews-criticism $>$. 
referrals for services at the QEII hospital in Halifax, which were entirely dependent on physician discretion, resulting in significance access inequality. Activist networks maintained lists of Prince Edward Island doctors willing to make referrals, given reports of refused referral for reason of personal belief or attempted extortion. ${ }^{127}$ The Prince Edward Island Medical Society remained silent on these practices, refusing to take a stand on an issue that divided its members. ${ }^{128}$ These are the same conditions of inequality that led the Supreme Court in Morgentaler to find the criminal law constitutionally flawed. ${ }^{129}$

Women without family physicians or strong networks had little hope of navigating Prince Edward Island's abortion rules and regulations. ${ }^{130}$ Many were pushed outside the system, sometimes into safe private care, but also toward unsafe clandestine practice. Health PEI's own statistics showed that prior to its closing in the summer of 2014, the Morgentaler Clinic in Fredericton, New Brunswick provided, at women's private expense, more than half of the abortion services received by Island women. ${ }^{131}$ Many women resorted to these services because the requirements for publicly-funded hospital-based care were so onerous. ${ }^{132}$ The MacQuarrie study also documented more desperate measures of resort, including selfinduction and self-injury. ${ }^{133}$

First person accounts emerged about the provision of medical abortion by local physicians through the off-label use of methotrexate and misoprostol, but with quality concerns about inadequate training and lack of post-abortion care. ${ }^{134}$ The issue captured mainstream media attention in May 2015 after a woman reported that she was denied post-abortion care at a local Prince Edward Island hospital after suffering complications from a medical abortion administered by a local physician. ${ }^{135}$ Following the incident, the P.E.I. Abortion Rights Network, a local activist group, released an open letter to the government demanding policy reform, ${ }^{136}$ but none was forthcoming.

Wright, "Women Share," supra note 123.

Teresa Wright, "Medical Society President Explains Silence on Abortion," The Guardian (29 November 2011), online: <www.theguardian.pe.ca/News/Local/2011-11-29/article-2819886/Medical-societypresident-explains-silence-on-abortion/1>.

Morgentaler, supra note 4 at 68 :

There has been no sustained or firm effort in Canada to develop an explicit and operational definition of health, or to apply such a concept directly to the operation of induced abortion. In the absence of such a definition, each physician and each hospital reaches an individual decision on this matter. How the concept of health is variably defined leads to considerable inequity in the distribution and the accessibility of the abortion procedure.

MacQuarrie, MacDonald \& Chambers, supra note 122 at 29-31.

"Premier Ghiz Backs Abortion Rights, No Plans for Local Access," CBC News (9 May 2014), online: $<$ www.cbc.ca/news/canada/prince-edward-island/premier-ghiz-backs-abortion-rights-no-plans-for-localaccess-1.2637115>.

Campbell, "In Depth," supra note 36.

MacQuarrie, MacDonald \& Chambers, supra note 122 at 34-37. See also Sarah Ratchford, "Why Rural Maritimers Are Practicing DIY Abortions," VICE Magazine (2 July 2015), online: <www.vice.com/en ca/read/why-rural-maritimers-are-practicing-diy-abortions $>$.

Ibid. See also McKenna, supra note 126.

Teresa Wright, "P.E.I. Woman Raising Concern Over ER Treatment Following Medical Abortion,” The Guardian (22 May 2015), online: <www.theguardian.pe.ca/News/Local/2015-05-22/article-4155862/ P.E.I.-woman-raising-concern-over-ER-treatment-following-medical-abortion/1>.

Letter from PEI Abortion Rights Network to Premier H Wade MacLauchlan and the Honourable Doug Curie (22 May 2015), online: <https://peiacsw.files.wordpress.com/2015/05/final-abortion-rights-lettermay-201.pdf $>$. 
The Prince Edward Island government carried out no investigation of abortion practice under its policy, including the local provision of medical abortion. ${ }^{137}$ MacQuarrie and her team sent their research findings to Health PEI in an effort to inform the government about the effects of the policy, but the government would only confirm that, according to its knowledge, "[t]here are no illegal abortions that occur on P.E.I. There are no back-alley abortion clinics on P.E.I., obviously, so we don't have illegal abortions."138 What the government failed to understand was that the unsafe provision of abortion care resulted not from illegal abortions, or more accurately those performed outside approved clinic or hospital settings, but rather from the government policy itself, which left women and providers without support or resources. In fact, the abortion policy only worked to the extent that it did because an army of local activists assisted women in accessing safe services, locally and out-of-province, by providing information, referrals, and support. ${ }^{139}$

Against these facts, AAN PEI argued that women suffered a deprivation of security of person not simply in government neglect, but government malfeasance in the maintaining and enforcing of an abortion policy that endangered the lives and health of women. ${ }^{140}$ This is not a novel claim. It is the way in which section 7's security of the person rights have been successfully litigated in the health care context, including in Morgentaler. ${ }^{141}$ To administer the provision of abortion services, or any health care service, in a way that denies or delays access, or that otherwise breeds conditions for unsafe access, infringes on the right to security of person. That a woman can escape these harmful effects through private funds or volunteer support is no claim to the policy's constitutional merit. ${ }^{142}$

The democratic force of the argument, however, resides in why this deprivation of security runs afoul of the basic values of the constitutional order, or in the language of section 7 , fails to accord with the principles of fundamental justice. ${ }^{143}$ In this part of the argument, AAN PEI drew out the normative significance of the health-related harms of the abortion policy, arguing that the abortion policy was manifestly unjust because it inflicted harm without reason. ${ }^{144}$ Its harms corresponded to no legitimate objective. To run this argument of arbitrariness, AAN PEI relied on its statutory argument of invalidity, the lack of a connection between out-of-province referral, and the values and objectives of the law, namely the equitable and efficient provision of care. The harm resulting from the policy was thus also arbitrary insofar as it too served no legitimate purpose.

MacQuarrie, MacDonald \& Chambers, supra note 122 at 23-26.

CBC News, "Lack of Abortion Access," supra note 84.

Alison Auld, "P.E.I. Women Continue to Face Barriers to Abortion Despite Easing of Restrictions," The Toronto Star (27 December 2015), online: <www.thestar.com/news/insight/2015/12/27/pei-womencontinue-to-face-barriers-to-abortion-despite-easing-of-restrictions.html>.

AAN PEI (Draft Notice of Application), supra note 7 at paras 68, 141-42. See also letter from Canadian Civil Liberties Association to the Honourable Doug Curie, Minister of Health and Wellness (11 November 2011), online: <https://ccla.org/cclanewsite/wp-content/uploads/2015/03/2011-11-11-Letterto-Minister-of-Health-FINAL.pdf $>$; Letter from the National Abortion Federation et al to Premier Robert WJ Ghiz and Minister Doug W Curie (28 May 2014), online: <impactethics.ca/2014/05/28/abortion $\mathrm{pei} />$.

Morgentaler, supra note 4. See also Bedford, supra note 124; Chaoulli v Quebec (Attorney General), [2005] 1 SCR 791 [Chaoulli ]; Canada (Attorney General) v PHS Community Services Society, [2011] SCR 44, [2011] 3 SCR 134; Carter v Canada (Attorney General), [2015] SCC 34, [2015] 1 SCR 331. Chaoulli, ibid at para 106.

See Bedford, supra note 124 where the Supreme Court described the principles of fundamental justice as capturing the basic values of our constitutional order.

AAN PEI (Draft Notice of Application), supra note 7 at paras 143-45. 
The principles of fundamental justice set normative and not strictly legal constraints on the exercise of public power. Underlying arbitrariness as a principle of fundamental justice lies a normative view of the affected person: that their life, liberty, and security has worth, that it is to be accounted for in any calculus of policy risk and benefit, and to state it bluntly, that government should care whether they live or die. ${ }^{145}$ This construction of abortion rights under section 7 of the Charter thus guarantees more than an individual right of security or protection. It is equally a claim on the state and its collective morality. The abortion policy is unconstitutional because it endangers the health of women in a way that runs afoul of fundamental constitutional values. Policy reform becomes necessary to avoid living in a state that would sacrifice its citizens to harm without reason.

Partly in answer to the rising criticism of its abortion policy, the Prince Edward Island government took efforts to improve access under it: information, travel support for lowincome women, and public funding for services at the Moncton Hospital. The assumption was that if the policy could be made to work, it would present no constitutional affront. AAN PEI disagreed. A government policy that requires its residents to leave the Island to access abortion care without reason, no matter how comfortable the journey, remains constitutionally offensive. Its offense lies once again in the normative view it communicates about women, their value and worth as citizens and as members of the political community. AAN PEI addressed these concerns through an equality rights claim under section 15(1) of the Charter. ${ }^{146}$

Section 15(1) guarantees that "[e]very individual is equal before and under the law and has the right to the equal protection and equal benefit of the law without discrimination and, in particular, without discrimination based on ... sex."147 To show inequality in treatment, AAN PEI again relied on its statutory argument of invalidity, namely that the government policy treats abortion differently than other health services under the Health Services Act. ${ }^{148}$ Abortion is subject to out-of-province referral, whereas equivalent ambulatory care is provided in clinics or hospitals on-Island. The abortion policy, in other words, is not an anticipated part of the legislative scheme. ${ }^{149}$ Moreover, because abortion is a pregnancyrelated service, its different treatment constitutes a distinction on the basis of sex. ${ }^{150}$ AAN PEI made a claim of entitlement to health care only in this respect: once the state provides a benefit, namely, local and safe access to ambulatory care, it is obligated to do so in a

Liston, "Governments in Miniature," supra note 40 at 80 . ("Arbitrariness ... necessarily involves a normative view of the affected person(s) ... [whether] the affected person is treated as if he or she has worth as an individual, a citizen, and a member of his or her political community.") The justification standard under section 1 of the Charter performs similar normative work: Eldridge v British Columbia (Attorney General), [1997] 3 SCR 624 [Eldridge] ("[t]he government has simply had not determined that this unpropitious state of affairs must be tolerated in order to achieve the objective of limited health care expenditures" at para 94). AAN PEI (Draft Notice of Application), supra note 7 at para 79

Charter, supra note 8, s 15(1).

AAN PEI (Draft Notice of Application), supra note 7 at paras 81-83; Quebec (Attorney General) $v$ A, 2013 SCC 5, [2013] 1 SCR 61 at paras 319-47 [Quebec AG]; Kahkewistahaw First Nation v Taypotat, 2015 SCC 30, [2015] 2 SCR 548 at paras 16-20 [Kahkewistahaw First Nation]. Auton (Guardian ad litem of) v British Columbia (Attorney General), 2004 SCC 78, [2004] 3 SCR 657 at 676 [Auton].

150 See Brooks v Canada Safeway Ltd, [1989] 1 SCR 1219 (the Supreme Court accepted that "[d]iscrimination on the basis of pregnancy is a form of sex discrimination" at 1242). 
nondiscriminatory manner, which may require extending the scope of benefits to include local abortion services. ${ }^{151}$

The democratic force of the argument, however, resides in why this difference of treatment constitutes discrimination, that is, why it runs afoul of the principle of substantive equality in intent or impact. As articulated in the section 15(1) jurisprudence, this principle speaks to the foundational idea that equality rights in Canada promise "a society in which all are secure in the knowledge that they are recognized at law as ... equally deserving of concern, respect and consideration." " 52 Equality rights have long embraced a citizenship ideal, promoting not merely tolerance, but a sense of belonging as full and equal members of a political community. ${ }^{153}$ To this end, there are some benefits and some institutions, which are so closely associated with citizenship that denying equal access to these benefits or full participation in these institutions purports to divest one of their citizenship status. Recalling the constitutional values of Medicare, access to health care is one such benefit, and a universal health care system one such institution. ${ }^{154}$ All Canadians are supposed equals in the domain of health care such that to be denied equality within this institution, and to have one's needs neglected and welfare disregarded, communicates a larger message about one's standing in the political community. This is the normative effect of discrimination in the health care context.

AAN PEI's argument that the abortion policy was discriminatory invoked these democratic effects of excluding Island women from the public health care system. ${ }^{155}$ For more than one hundred and fifty years, women who terminated their pregnancies were a criminal class. ${ }^{156}$ Not only was abortion linked to undesirable moral qualities, but it was also perceived as a threat to family, community, and nation by virtue of the moral transgressions it represented. The campaign to criminalize abortion in the nineteenth century reflected and reinforced the prevailing moralities of a deeply patriarchal but also racist society. ${ }^{157}$ This campaign traded on fears of 'race suicide' with the relative decline of English Canadians' birth rate against that of French Canadians and the influx of non-British migration. ${ }^{158}$ These women were perceived as neglecting their duties to husband, race, and state, and were devalued, rejected, and punished for it.

Criminal law was the legal instrument for this punitive work, but in the Canadian welfare state, exclusion from collective social programs assumed its place. ${ }^{159}$ In 1993, the Supreme Court of Canada struck down a Nova Scotia law that both prohibited the provision of, and denied public funding for, abortions performed outside of hospitals. The Court read these

Eldridge, supra note 145 at paras 73-74.

Andrews v Law Society of British Columbia, [1989] 1 SCR 143 at 171.

Erdman, supra note 51 at 1129-34.

Robert G Evans, "'We'll Take Care of It for You': Health Care in the Canadian Community" (1988) 117:4 Daedalus 155 at 165 .

AAN PEI (Draft Notice of Application), supra note 7 at paras 105-109.

For an extended study of the criminalization of abortion in Canada, see Shelley Gavigan, "The Criminal Sanction as it Relates to Human Reproduction: The Genesis of the Statutory Prohibition of Abortion" (1984) 5:1 J Leg Hist 20.

Angus McLaren, "Birth Control and Abortion in Canada, 1870-1920" (1978) 59:3 Can Hist Rev 319 at $320-21$.

Louise Falconer, "The Mother Country and Her Colonial Progeny" (2003) 7 L Text \& Culture 149 at 150.

See Candace Johnson Redden, "Health as a Citizenship Narrative" (2002) 34:3 Polity 355. 
restrictions as an indivisible attempt by the province to legislate in the area of criminal law — that is, to regulate abortion as socially undesirable conduct. ${ }^{160}$ In its most recent case on equality rights, the Supreme Court affirmed that "[i]f the state conduct widens the gap between the historically disadvantaged group and the rest of society rather than narrowing it, then it is discriminatory." 161 Building on these precedents, AAN PEI argued that a health care system that perpetuates the historic disadvantage that women suffered under the criminal abortion law raises a strong presumption that a continuing and entrenched prejudice against these women motivates its design. ${ }^{162}$ The government's policy keeps alive the moralism of the former criminal law by denying women public support for abortion care and by quite literally banishing them from the Island to receive care. Through the administration of health care, the government marginalizes Island women, using their perceived moral transgression as justification for this exercise of public power. ${ }^{163}$

In rehearsing this narrative of the abortion policy, constructed through an equality rights claim, AAN PEI raised a suspicion of illicit purpose in the abortion policy, a prejudice otherwise buried in the government's benign claims about how the status quo is working, or of the bureaucratic need for regionalized care. ${ }^{164}$ The assumptive illicitness of the policy required government to dig deeper for reason in its policy-making, to explain why abortion care is referred off-island in a regionalization strategy, why physician referral of medical need is required for public funding, and why such funding is limited to hospital provision. As constructed by AAN PEI, equality rights imposed on government an obligation to give reason for the abortion policy less the assumption carries that it is based on prejudice alone. AAN PEI asked government to show that the character of this place had changed, that women who exercised their reproductive liberties were no longer personae non gratae, perceived as a threat to the state and deserving not of its protection.

Through equality rights, AAN PEI once again challenged the government's claim to absolute and unfettered discretion in its policy-making. They asked the government to give reason for the abortion policy, reason giving being essential to the non-arbitrary exercise of public power by communicating a basic respect for those to whom reason is owed. ${ }^{165}$ The entitlement that AAN PEI claimed for Island women under the equality rights of the Charter

$R v$ Morgentaler, [1993] 3 SCR 463 at 464, 513. In Lexogest, supra note 99, a majority of the Manitoba Court of Appeal declared a regulation restricting insurance coverage for abortion services invalid. The majority judgment addressed the context of the regulation's enactment and its ultimate effect: "I would be closing my eyes to the reality that exists outside the four corners of the court-room if I failed to note that the challenged regulation was passed immediately following the Supreme Court decision in $R$. $v$. Morgentaler... The effect of the regulation is to provide insurance coverage only for the patient who chooses to have her therapeutic abortion performed in a hospital, as the situation existed prior to the Morgentaler decision" (Lexogest, ibid at 561 [citations omitted]).

Kahkewistahaw First Nation, supra note 148 at para 20, citing Quebec AG, supra note 148 at para 332. AAN PEI (Draft Notice of Application), supra note 7 at paras 87-89, 96-100, 118-20. In designing a public health insurance plan, "[i]t is not open to ... a legislature to enact a law whose policy objectives and provisions single out a disadvantaged group for inferior treatment," Auton, supra note 149 at para 41.

Roncarelli, supra note 1 at 141: "To deny ... because a citizen exercises ... [a] right totally irrelevant to the [purpose of the legislation] is equally beyond the scope of discretion conferred." AAN PEI (Draft Notice of Application), supra note 7 at paras 84, 116.

Liston, "Witnessing Arbitrariness," supra note 28 ("both liberal and republican philosophies take reason-giving to be an essential legitimating factor, communicating legal and political equality, and creating a permanent public law duty on government that assists in mitigating actual and potential public acts of domination" at 715). See also Fox-Decent, supra note 34 ("[1] egal principles such as, fairness, purposiveness, and reason-giving provide a bulwark against the possession and use of arbitrary power" at 523). 
was an entitlement to an abortion policy that evidenced regard for the health and well-being of women, their actual and material needs, and their desires as voiced from their experiences and perspectives. They made a claim for an abortion policy that not only ensured women access to safe and local services, but that also recognized women as full and equal citizens of a democratic order.

\section{CONCLUSION}

Although retrospective in its orientation, this case study carries a prospective agenda. It offers a constitutional future for abortion rights in Canada through the study of a mobilized group of citizens in a small Atlantic province. The form and content of their legal claims challenged the government policy on abortion as symptomatic of a deeper political conflict over the terms of women's citizenship. They claimed abortion rights for more than access to a single health care service. They claimed abortion rights as democratic rights: the right to fully and equally participate in, and to benefit from, the institutions of the state, the health care system among them. They claimed for reproductive justice.

Abortion rights in Canada have long been rooted in an abstract liberal individualism, divorced from the real and material contexts of women's lives, and the social and economic institutions that shape them. The idea of reproductive justice, conceived by women of colour in the United States, is to expose and challenge the structures of power, private and public, that prevent women from enjoying liberty, security, and equality in their sexual and reproductive lives. ${ }^{166}$ Reproductive justice endeavours to reveal a political space beyond mere access to services, a space in which to build social institutions in the public interest that speaks to a community's diverse needs and values: to have or not to have children, to enjoy sex without violence, and to parent with dignity.

When AAN PEI launched their challenge, they charged the government with "flouting the spirit" of Morgentaler. ${ }^{167}$ Yet by their challenge, these activists redefined its spirit, reclaimed its legacy, and set a new course for the future of abortion rights in Canada. 328, 337, citing Loretta J Ross, Understanding Reproductive Justice (Atlanta: SisterSong, 2006) and Jael Silliman et al, Undivided Rights: Women of Color Organize for Reproductive Justice (Cambridge, Mass: South End, 2004).

167 "P.E.I. Abortion Advocates to Sue for Access on Island," CBC News (5 January 2016), online: $<$ www.cbc.ca/news/canada/prince-edward-island/abortion-lawsuit-pei-1.3389889>. 
